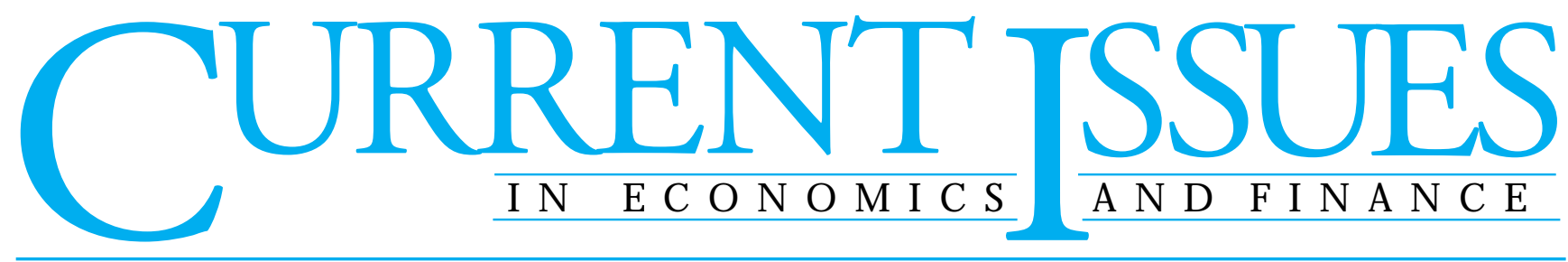

June 1998

Volume 4 Number 6

\title{
How Effective Is Lifeline Banking in Assisting the 'Unbanked'?
}

\author{
Joseph J. Doyle, Jose A. Lopez, and Marc R. Saidenberg
}

\begin{abstract}
Many consumers who lack checking accounts are paying relatively high costs to access the nation's payments system. Legislation aimed at opening the system to these unbanked individuals has centered on requiring commercial banks to offer low-cost "lifeline" accounts. But will cost savings alone motivate these consumers to access the payments system through banks?
\end{abstract}

According to the Federal Reserve System's 1995 Survey of Consumer Finances, more than 10 million Americans do not have a checking account. These "unbanked" citizens are found in disproportionately high numbers in the lowincome population: about 40 percent of families with incomes below $\$ 10,000$ lack a checking account, as opposed to just 1 percent of families with incomes above $\$ 50,000$.

Consumer advocates argue that bank fees and minimum balance requirements have deterred low-income families from establishing relationships with banks. Prompted by fairness concerns, these advocates have called for reforms that would ensure inexpensive access to the payments system-the system that makes the transfer of funds between individuals and firms possible. Such access will be particularly important after 1999, when the 1996 Balanced Budget Down Payment Act will require that all federal government transfer payments, including social security and welfare payments, be made electronically.

In this edition of Current Issues, we examine one reform that has been implemented in a few states and is under consideration at the federal level-a requirement that commercial banks offer low-cost banking accounts known as "lifeline," or basic, accounts. We assess the degree to which these accounts reduce costs and evaluate their effectiveness in drawing the unbanked into the payments system.
Our analysis suggests that lifeline accounts will have only a limited impact on the unbanked. Many banks voluntarily offer accounts priced below lifeline accounts. Moreover, consumers who currently lack checking accounts appear relatively unresponsive to small changes in the price of payments services. We conclude that pricing reform must be accompanied by policies promoting consumer education and more convenient banking services if it is to persuade the unbanked that they have something to gain from accessing the payments system through depository institutions.

\section{Lifeline Banking}

Lifeline banking laws were first proposed in several states in the early-to-mid-1980s. ${ }^{1}$ Thus far, seven statesIllinois, Massachusetts, Minnesota, New Jersey, New York, Rhode Island, and Vermont—have enacted legislation creating lifeline banking accounts. These laws range from authorizing the state banking department to monitor bank fees and, when appropriate, regulate them, to mandating that all state-chartered banks offer a low-cost checking account. ${ }^{2}$ At the federal level, amendments to financial reform bills currently under debate would require all banks to offer lifeline banking accounts.

The New York State law is a good example of a comprehensive form of lifeline legislation. The Omnibus 
Consumer Protection and Banking Deregulation Act, enacted in January 1995, requires state-chartered banks in New York to offer low-cost checking accounts. Such accounts can be opened with as little as \$25, have no minimum balance requirement, carry a maximum maintenance fee of $\$ 3$ per month, and must allow at least eight monthly transactions (New York State Banking Department 1996b).

From a policy perspective, two conditions must be met for lifeline banking legislation to provide the unbanked with greater access to the payments system: the legislation must reduce the price of payments services, and consumers must be sensitive to this price change. It appears that while lifeline accounts lower some payments services costs, many consumers may not be sensitive to these price changes.

\section{Reduced Pricing}

Although detailed information on the use of lifeline accounts is not available, lifeline legislation clearly lowers the price of payments services for some consumers. Its proponents argue that in addition to drawing the unbanked into the traditional banking system, lifeline legislation offers this group inexpensive access to the payments system in two ways: by lowering the minimum opening balance requirement - an important barrier to opening an account-and by reducing the monthly maintenance costs they would pay at some banks. The New York State law addresses both of these cost factors directly: banks must offer accounts with no minimum balance requirement and can impose only a low, fixed cost for a set number of monthly transactions.

Indeed, a 1996 study by the Office of the Public Advocate for the City of New York confirms that lifeline accounts at some New York City banks were significantly less expensive than other accounts offered (Green and Leichter 1996). The same study, however, showed that roughly 25 percent of the forty-eight banks surveyed had low-balance checking accounts that were actually less expensive for the consumer than the mandated lifeline accounts. ${ }^{3}$ The 1998 update of the Public Advocate's study again shows that roughly 25 percent of the fifty surveyed banks-which represent about 20 percent of New York City branches and 10 percent of deposits-offer accounts with lower monthly fees than the legislated accounts (Green and Leichter 1998). Thus, while lifeline legislation has reduced consumer costs at some banks, it has not significantly changed these costs at others.

\section{Price Sensitivity}

Lifeline banking will achieve its goals only if the unbanked are sensitive to the cost advantages it offers them. To investigate the extent to which the unbanked respond to changes in price, we explore how these con- sumers currently access the payments system and we compare the associated costs with those of banks.

Accessing the Payments System: Check-Cashing Outlets versus Banks. Families without bank accounts find alternative ways to receive and make paymentsmost notably, they use check-cashing outlets. Instead of depositing and writing checks, outlet users can cash checks for a fee and pay bills directly with cash or indirectly by purchasing money orders. The outlets, which are located mostly in metropolitan areas, offer a wide range of other products, such as money wiring, utility payment services, notary public services, and various convenience store items.

Nationally, the check-cashing industry has grown steadily over the past few years, increasing from 2,000 outlets in 1986 to 6,000 by 1995 , according to the National Check Cashers Association (Milligan 1996). Even major financial institutions such as Chase Manhattan and GE Capital have expanded into this area. ${ }^{4}$ Recently, some state legislatures have increased

Lifeline banking will achieve its goals only if the unbanked are sensitive to the cost advantages it offers them.

the legal maximum on check-cashing fees-a step that has aided this growth. In 1995, New York State had 560 check-cashing outlets, about 90 percent of which were in New York City. New York outlets cashed approximately 31 million checks in 1995, 6 percent more than they did in 1990; these checks had a total face value of more than $\$ 10$ billion, up 13 percent from their 1990 value (New York State Banking Department 1996a).

Despite the growing popularity of check-cashing outlets, access to the payments system by this means is relatively expensive (Table 1). In New York, the outlets typically charge the legal maximum of 1.1 percent of the face value of the check. Thus, a family of four at the 1997 federal poverty level of $\$ 15,600$ annual income would pay $\$ 172$ to cash all of their paychecks. By comparison, the 1998 study by the Office of the Public Advocate for the City of New York calculated that the median cost of a lowbalance checking account at New York City banks was just \$44 per year (Green and Leichter 1998). ${ }^{5}$ In fact, all surveyed banks charged less than the $\$ 172$ check-cashing fee, and about 80 percent charged less than half of that fee. The price gap between banks and check cashers becomes even wider when bill payment is considered. 
Table 1

\section{Consumer Costs: Check-Cashing Outlets versus Banks}

\begin{tabular}{lccc}
$\begin{array}{c}\text { Annual } \\
\text { Income }\end{array}$ & \multicolumn{3}{c}{ Cost of Cashing One Year's Paychecks } \\
\hline $\begin{array}{c}\text { At a Check- } \\
\text { Cashing Outlet }\end{array}$ & At a Bank & $\begin{array}{c}\text { Potential } \\
\text { Savings }\end{array}$ \\
\hline$\$ 10,000$ & $\$ 110$ & $\$ 44$ & $\$ 66$ \\
$\$ 7,855^{\mathrm{a}}$ & $\$ 86$ & $\$ 44$ & $\$ 42$ \\
$\$ 15,600^{\mathrm{b}}$ & $\$ 172$ & $\$ 44$ & $\$ 128$ \\
\hline
\end{tabular}

Source: Green and Leichter (1998).

Notes: Outlet costs are calculated as 1.1 percent of annual income. Bank costs are the median cost of low-balance checking and savings accounts at fifty New York City banks.

${ }^{a}$ The 1997 poverty level for one person.

${ }^{\mathrm{b}}$ The 1997 poverty level for a family of four.

The $\$ 44$ bank account cost covers the writing of eight checks per month. If money orders are bought as substitutes for checks, then the price of using the check-cashing outlets increases even further. ${ }^{6}$

Another way to illustrate this price gap is through the cost associated with the liquidity advantage provided by check cashers. For example, a consumer could deposit a $\$ 100$ check in a bank and, after it has cleared, withdraw the full amount three days later, or instead go to a check casher charging 1.1 percent of the value of the check and receive $\$ 98.90$ immediately. In effect, the check casher is providing a three-day loan to the consumer for an interest payment of $\$ 1.10$. This $\$ 1.10$ payment for a three-day loan, when calculated as an annualized percentage rate, is equivalent to an annual interest rate of 133 percent. This effective rate is significantly higher than other consumer loan rates currently available.

Are the Unbanked Price Sensitive? While data limitations prevent precise estimation of the change in the quantity of payments services demanded given a change in price, it appears that the customers of check-cashing outlets are generally not very sensitive to small price changes. Several observations support this contention.

First, note that approximately 9 percent of families did not have a checking account in 1977-a year when interest rate ceilings were in effect and checking accounts were free or inexpensive (Canner and Maland 1987). Second, only 17 percent of families without checking accounts in 1995 specifically identified minimum balance requirements and service charges as the main reasons for not having an account (Table 2). Third, if the unbanked were sensitive to small cost differences, they would not be paying the relatively high effective rates charged by the check-cashing industry.
Their willingness to do so suggests that they do not regard the services of the outlets and banks as close substitutes. What most likely distinguishes the services of the outlets from those of banks is the immediate availability of funds. For many outlet customers, this advantage may outweigh all other considerations. If the unbanked need to pay bills as soon as they receive a paycheck-or face substantial penalties if they delay payment - they may choose to pay an outlet the high liquidity premium. In this case, even free checking would not induce outlet users to open a bank account. Overall, these observations suggest that cost is not the primary motivating factor among the unbanked. Consequently, a marginal, legislated decrease in banking costs is not likely to prompt outlet customers to switch to lifeline banking.

Finally, the impact of two regulatory developments supports our argument that the outlet customers are not particularly sensitive to changes in the relative cost of banking services. First, legislation over the last two decades has reduced the maximum number of days that a bank can hold a check for clearing; this change has raised the effective interest rate on the "short-term loans" that check-cashing outlets offer. Despite these higher rates, consumer use of the outlets has grown over this period. Second, New York State's legal maximum check-cashing fee was raised from 0.9 percent to 1.1 percent in 1992, while bank fees remained nearly constant in real terms. Meanwhile, outlets in the state continued to cash more consumer checks and earn higher revenues annually. ${ }^{7}$

\section{Table 2 \\ Reasons Cited by Unbanked Families for Not Having a Checking Account}

\begin{tabular}{lrrr} 
Reason & 1989 & 1992 & 1995 \\
\hline $\begin{array}{l}\text { Do not write enough checks } \\
\text { to make it worthwhile }\end{array}$ & 34 & 30 & 27 \\
$\begin{array}{l}\text { Do not like dealing with banks } \\
\text { Do not have enough money }\end{array}$ & 15 & 15 & 23 \\
$\begin{array}{l}\text { Minimum balance is too high } \\
\text { Cannot manage or balance }\end{array}$ & 8 & 9 & 9 \\
$\begin{array}{l}\text { a checking account } \\
\text { Service charges are too high }\end{array}$ & 5 & 6 & 9 \\
$\begin{array}{l}\text { No bank has convenient } \\
\text { hours or location }\end{array}$ & 8 & 11 & 8 \\
$\begin{array}{l}\text { Other } \\
\text { Total }\end{array}$ & 1 & 1 & 1 \\
\hline
\end{tabular}

Source: Survey of Consumer Finances (Kennickell, Starr-McCluer, and Sundén 1997).

Note: Figures are in percentages. 


\section{Alternative Policy Prescriptions}

We have argued that lifeline legislation will be effective only if the new accounts reduce the price of payments services and if the unbanked are responsive to such reductions in price. Although lifeline banking often does lower costs, many other accounts are already priced below the lifeline accounts. Moreover, as we have argued, the unbanked are relatively unresponsive to small price changes. Therefore, banking policy initiatives aimed at assisting the unbanked should not be limited to price reform. Policies focusing on the reasons why consumers choose to pay a premium to access the payments system through bank alternatives may be equally useful. We explore three such reasons and the policy initiatives that might address them.

\section{Locational Convenience}

Locational convenience provides one explanationthough a partial one-for consumer willingness to pay the relatively high fees charged by check-cashing outlets. Representatives of the check-cashing industry

\section{Banking policy initiatives aimed at assisting the unbanked should not be limited to price reform.}

often cite convenience as a competitive advantage over banks. They argue that the outlets have more accessible locations than banks-especially for low-income families-as well as shorter lines and more attractive hours of operation.

Some support for these claims comes from journalists and researchers who contend that check-cashing outlets outnumber bank branches in low-income neighborhoods. Reeb (1991), for example, found that as of June 1990, just under 70 percent of all outlets in New York City were in low-income census tracts. Moreover, as of June 1995, 29 percent of the outlets in New York City were in ZIP code areas with no bank branches (Table 3). Nevertheless, many neighborhoods are served by both check-cashing outlets and banks; in the case of New York City, 71 percent of the city's outlets share a ZIP code area with at least one bank branch, and about 19 percent of outlets are in areas with more than ten bank branches.

Although the importance of locational convenience may be overstated, policy reforms could bring lower cost access to the payments system to a broader group of communities. For example, zoning reform that allows large retail stores to open in urban areas could
Table 3

Locations of New York City Check-Cashing Outlets in Relation to Bank Branches

\begin{tabular}{lcc}
$\begin{array}{l}\text { Number of Bank } \\
\text { Branches in } \\
\text { a ZIP Code Area }\end{array}$ & $\begin{array}{c}\text { Number of Outlets } \\
\text { in Those } \\
\text { ZIP Code Areas }\end{array}$ & $\begin{array}{c}\text { Outlets as a } \\
\text { Percentage of All } \\
\text { New York City Outlets }\end{array}$ \\
\hline 0 & 142 & 29 \\
$1-5$ & 149 & 30 \\
$6-10$ & 107 & 22 \\
$11-20$ & 52 & 11 \\
More than 20 & 39 & 8 \\
$\quad$ Total & 489 & 100 \\
\hline
\end{tabular}

Sources: New York State Banking Department; SNL Branch Migration DataSource version 1.5; U.S. Postal Service.

also give the unbanked increased access to financial services through "supermarket branches." 8 These branches, which are established by banks in retail stores, offer many traditional banking services. They are accessible, relatively safe, and open long hoursattributes that allow them to compete directly with check cashers in terms of convenience.

Another policy initiative that may encourage banks to become more active in "underserved" areas is the creation of "banking development districts." One such undertaking, launched recently in New York State, allows banks and local governments to file jointly to establish areas where local government can offer property tax breaks and guarantees of government deposits to banks that set up new branches. Legislators hope that initiatives of this type will aid economic development as well as motivate area residents to join the financial mainstream. ${ }^{9}$

\section{Consumer Sentiment}

Consumers may also choose alternatives to banks because of their dissatisfaction with bank services. For instance, 23 percent of people without bank accounts claim they do not like dealing with banks (Table 2). Another 9 percent say they cannot manage or balance a checking account. The owners of check-cashing outlets note that they compete effectively with banks in the area of customer service and satisfaction by stressing fast, friendly, and convenient service. Greater responsiveness to consumer preferences may help account for the outlets' large and growing client base.

Consumer preferences are difficult to address through public policy initiatives, but some options are available. Legislation designed to foster more convenient banking services-and greater awareness of those services-may improve consumer sentiment toward the banking system. For example, initiatives 
aimed at educating consumers about electronic funds transfer may help familiarize the unbanked with the ease and convenience of automated teller machines. ${ }^{10}$

\section{Information Costs}

The cost or difficulty of acquiring information about the price gap between check-cashing outlets and traditional banks may also help explain why consumers choose to pay a premium for the services of outlets. That is, if information about the price of banking services is difficult or costly to obtain, it may be sensible for consumers to continue using the outlets, even though they are paying more than they would be using lifeline accounts. Anecdotal evidence suggests, however, that some outlet customers are making an uninformed choice. For example, a 1989 study by the Consumer Bankers Association showed that while most outlet customers realized that banks were less expensive than outlets, more than 30 percent of customers without a bank account either did not know which was more expensive or thought that banks were more expensive. ${ }^{11}$

In policy terms, initiatives that reduce the cost of collecting price information on financial services could directly help the unbanked. Such efforts could stand alone or be part of the conversion to electronic funds transfer. Educating consumers about the price gap between the cost of payments services at banks and bank alternatives would at least help them to make more informed choices.

\section{Conclusion}

The fact that some consumers, particularly low-income families, pay relatively high prices for access to the payments system is a policy concern. Recent initiatives at the state level have focused on lowering the price of banking services and encouraging the unbanked to use more traditional payment methods. Our analysis indicates that such initiatives, although helpful, may have a limited impact for two reasons.

First, recent surveys of New York City banks indicate that lifeline banking legislation may not significantly lower consumer costs since many banks already voluntarily offer services priced below the mandated maximums. Moreover, even if costs are reduced, many of the unbanked appear to be relatively unresponsive to such price changes. Thus, policy initiatives that are not price-based should also be considered. In particular, measures that increase the convenience of banking services and inform consumers of the potential savings from using these services could prove effective in assisting the unbanked.

\section{Notes}

1. The elimination of deposit rate ceilings in the 1980s led banks to price checking account services explicitly. This development prompted consumer advocates to argue that some people would not be able to afford banking services (see Canner and Maland [1987]).

2. Massachusetts requires banks to offer no-fee savings and checking accounts to people over sixty-five or under eighteen. Rhode Island and Minnesota require banks to offer no-fee savings accounts, and Minnesota is also debating lifeline checking legislation. New Jersey and New York have lifeline checking legislation of the type described, while Illinois has similar legislation that applies to senior citizens only. Finally, Vermont conducts a quarterly survey of bank prices, and the state banking department has the authority to regulate prices if necessary; currently, there are no price regulations in Vermont.

3. The authors of the study calculate the cost of a low-balance account based on their profile of a low-balance bank customer. Such a customer is said to have an average balance of $\$ 750$ and make eleven transactions each month. The cost of these accounts to the customer is calculated as the annual fees minus interest earned. Opening balance requirements are not incorporated in the cost.

4. For a more complete discussion of recent entries into the checkcashing industry, see Branch (1998).

5. The $\$ 44$ cost includes the interest earned on the $\$ 750$ average balance held by the survey's low-balance bank customer. For customers with less than that amount, the actual cost may be higher.

6. The fee associated with money orders is not set by legislation. A 1994 study by the Office of the Public Advocate for the City of New York estimates that cashing checks and using money orders to pay bills costs up to $\$ 200$ to $\$ 250$ per year (Green and von Nostitz 1994). Burt (1991) estimates the annual cost of cashing checks and paying bills to be between $\$ 84$ and $\$ 297$ at a check-cashing outlet, compared with $\$ 10$ to $\$ 40$ at a bank, depending on usage.

7. See Board of Governors of the Federal Reserve System (1992, 1996). Other states also increased the legal maximum check-cashing fee (see Caskey [1996]).

8. See Radecki, Wenninger, and Orlow (1996) for a discussion of these branches and similar banking developments.

9. More details on banking development districts can be obtained from Newsday (1998) and New York State Banking Department (1998).

10. Note that while many respondents to the Survey of Consumer Finances indicate that they choose not to use checking accounts because they are dissatisfied with bank services, others cite different reasons (Table 2). The largest percentage of respondents claim that they do not write enough checks to make opening an account worthwhile; others indicate that banking services are too expensive. Given that Table 1 provides evidence that check-cashing outlets are more expensive than banks, some respondents may have other, less expensive access to the payments system; for example, they may cash checks at a merchant at no cost and pay bills in cash.

11. While this study may be biased because only users of checkcashing outlets were surveyed, it nevertheless shows that a lack of information is partly responsible for the use of these more costly outlets. For a more in-depth discussion of the study, see Caskey (1996). 


\section{References}

Board of Governors of the Federal Reserve System. 1992. "Annual Report to Congress on Retail Fees and Services of Depository Institutions." Washington, D.C.

1996. "Annual Report to Congress on Retail Fees and Services of Depository Institutions." Washington, D.C.

Branch, Shelly. 1998. "Where Cash is King." Fortune, June.

Burt, Henry. 1991. "Comparing Check-Cashing Stores to Affordable Banking Alternatives in New York State." In Economic Profile of the Check Cashers' Industry. Albany, N.Y.: State University of New York at Albany.

Canner, Glenn B., and Ellen Maland. 1987. "Basic Banking." Federal Reserve Bulletin, April.

Caskey, John P. 1996. Fringe Banking: Check-Cashing Outlets, Pawnshops and the Poor. New York: Russell Sage Foundation.

Green, Mark, and Franz S. Leichter. 1996. Ranking Banking: The Consumer Bank Scorecard. New York: Office of the Public Advocate for the City of New York.

1998. Ranking Banking: The Consumer Bank Scorecard. New York: Office of the Public Advocate for the City of New York.

Green, Mark, and Glenn von Nostitz. 1994. The Poor Pay More... for Less. Pt. 4, Financial Services. New York: Office of the Public Advocate for the City of New York.
Kennickell, Arthur B., Martha Starr-McCluer, and Annika E. Sundén. 1997. "Family Finances in the U.S.: Recent Evidence from the Survey of Consumer Finances." Federal Reserve Bulletin, January.

Milligan, John W. 1996. "A Philosophical Reflection upon the Metaphysical Nature and Existential Dilemma of Check Cashers." USBanker, July.

Newsday. 1998. "Dollars and Cents: Trying to Lure More Banks to Needy Areas." June 11.

New York State Banking Department. 1996a. Check Casher Summary Figures, July 16.

1996b. Basic Banking Accounts/Lifeline Banking Accounts, August 7.

1998. "Proposed Part 8 of the General Regulations of the Banking Board: Banking Development Districts.”

Radecki, Lawrence J., John Wenninger, and Daniel K. Orlow. 1996. "Bank Branches in Supermarkets." Federal Reserve Bank of New York Current Issues in Economics and Finance 2, no. 13 (December).

Reeb, Donald. 1991. "The Supplementary Services of CheckCashing Stores." In Economic Profile of the Check Cashers' Industry. Albany, N.Y.: State University of New York at Albany.

\section{About the Authors}

Joseph J. Doyle, formerly an assistant economist in the Banking Studies Function of the Research and Market Analysis Group, is a Ph.D. candidate in economics at the University of Chicago. Jose A. Lopez and Marc R. Saidenberg are economists in the Banking Studies Function.

The views expressed in this article are those of the authors and do not necessarily reflect the position of the Federal Reserve Bank of New York or the Federal Reserve System.

Current Issues in Economics and Finance is published by the Research and Market Analysis Group of the Federal Reserve Bank of New York. Dorothy Meadow Sobol is the editor.

Editorial Staff: Valerie LaPorte, Mike De Mott, Elizabeth Miranda Production: Carol Perlmutter, Lingya Dubinsky, Jane Urry

Subscriptions to Current Issues are free. Write to the Public Information Department, Federal Reserve Bank of New York, 33 Liberty Street, New York, N.Y. 10045-0001, or call 212-720-6134. Current Issues is also available at the Research and Market Analysis Group's web site: www.ny.frb.org/rmaghome. 